\title{
Setting time evaluation of injectable carbonate apatite cement using various sodium carboxymethylcellulose $(\mathrm{Na}$ CMC) concentration
}

\author{
"Arief Cahyanto*, Indah Permatasari*, Renny Febrida** \\ *Department of Dental Materials Science and Technology Faculty of Dentistry Universitas \\ Padjadjaran, Indonesia
}

\begin{abstract}
Introduction: The injectable calcium phosphate cement has the advantage to be used in the bone defect with the limited access which supports a minimally invasive surgical technique. These injectability properties of calcium phosphate cement can be modified by adding a sodium carboxymethylcellulose ( $\mathrm{Na}$ CMC). The aim of this present study is to investigate the setting time of injectable bone cement based on CO3Ap using various $\mathrm{Na}$ CMC concentration. Methods: Vaterite (a polymorph of $\mathrm{CaCO}$ ) and Dicalcium Phosphate Anhydrous (DCPA) as powder phase mixed with $0.2 \mathrm{~mol} / \mathrm{L} \mathrm{Na2HPO} 4$ solution containing 1\% polyethylene glycol (PEG) and various concentration of $\mathrm{NaCMC}$ as followed $0.5 \%, 1 \%, 1.5 \%$, and $2 \%$, respectively. Each concentration groups was consisting of 5 samples from total 20 samples. Powder and liquid phase was mixed with a spatula at a liquid to powder (L/P) ratio of 0.4. The setting time of CO3Ap cement was evaluated according to the modification method standardized by ISO 1566 for dental zinc phosphate cement using a custom fabricated Vicat needle apparatus. The cement was maintained at $37^{\circ} \mathrm{C}$ and $100 \%$ relative humidity as a standard requirement. Results: The mean value of setting time cement was as followed $0.5 \% \mathrm{Na}$ CMC 35:06 minutes, $1 \% \mathrm{Na}$ CMC 38:48 minutes, 1.5\% Na CMC 40:06 minutes, and $2 \% \mathrm{Na}$ CMC $41: 30$ minutes. The result is statistically significant $(\mathrm{p}<0.05)$ with the group of $0.5 \% \mathrm{Na}$ CMC compared to others group. Conclusion: Increasing the concentration of $\mathrm{NaCMC}$ could prolong the setting time of CO3Ap cement.
\end{abstract}

Keywords: Injectable carbonate apatite cement, setting time, sodium carboxymethylcellulose.

p-ISSN: 1979-0201; e-ISSN: 2549-6212; Available from: http://jurnal.unpad.ac.id/pjd/editor/submission/18321

DOI: http://dx.doi.org/10.24198/pjd.vol30no2.18321

Submission: May 24, 2018; Accepted: June 29, 2018; Published online: July 31, 2018

\section{INTRODUCTION}

An inorganic phase of calcified tissue of tooth and bone are known as biological apatite $\left[\mathrm{Ca}_{10}(\mathrm{PO} 4)_{6}(\mathrm{OH})_{2}\right] \cdot{ }^{1}$ However, apatite in tooth and bone also consisted of carbonate ions $(\mathrm{Ca})_{10}\left(\mathrm{PO}_{4}\right.$, $\left.\mathrm{CO}_{3}, \mathrm{HPO}_{4}\right)_{6}\left(\mathrm{CO}_{3}, \mathrm{OH}\right)^{2}$ in their formula which is similar to biological apatite, so-called carbonate apatite $\left(\mathrm{CO}_{3} \mathrm{Ap}\right) .{ }^{2}$ Calcium phosphate cement (CPC) based on the composition of the product can be

\#Corresponding author: Arief Cahyanto, Department of Dental Materials Science and Technology, Faculty of Dentistry, Universitas Padjadjaran, Indonesia

Sekeloa Selatan I, Bandung 40132, Indonesia. Phone: +62 812-1960-2295. E-mail: arief.cahyanto@fkg.unpad.ac.id 
divided into apatite and brushite forming cement. ${ }^{2}$

Bone cement formulations consist of vaterite (a polymorph of $\mathrm{CaCO}_{3}$ ) and dicalcium phosphate anhydrous (DCPA) as powder phase mixed with sodium phosphate solution can fully transform to $\mathrm{CO}_{3} \mathrm{Ap}$ in physiological conditions. ${ }^{3,4,5}$ Based on the previous study, this $\mathrm{CO}_{3} \mathrm{Ap}$ cement with L/P ratio of 0.45 will set in 11 minutes. ${ }^{3,4,5}$ The powder formulation is $40 \mathrm{wt} \%$ of vaterite and $60 \mathrm{wt} \%$ of DCPA were required for the full formation of $\mathrm{CO}_{3} \mathrm{Ap}{ }^{3,4,5}$

Apatite cement can be used to repair bone defects such as alveolar bone defect and dental implant fixation. ${ }^{6}$ The injectable cement type was more favor in dentistry which used to reach a small and narrow bone defect. The addition of a gelling agent can increase the injectability of cement. ${ }^{7}$ One of the biocompatible gelling agents is a cellulose derivative. Sodium carboxymethylcellulose $(\mathrm{Na}$ CMC) is a gelling agent derivate cellulose which can increase injectability and washout resistance cement. ${ }^{8}$ Washout resistance is an important property of cement. Blood and body fluids can affect the cement settings time, in order to apply in the body, cement must have washout resistance properties. ${ }^{7}$ CPC with the addition of CMC may turn to have washout resistance within 2 minutes. ${ }^{9}$

Gelling agent derivatives cellulose can affect the cement set. ${ }^{7}$ CMC can increase hardening time to 60 minutes. ${ }^{9}$ The purpose of this present study is to investigate the setting time of injectable bone cement based on $\mathrm{CO}_{3} \mathrm{Ap}$ using various $\mathrm{Na} \mathrm{CMC}$ concentration.

\section{METHODS}

The research type was experimental in-vitro. Materials used in this research were injectable bone cement based on $\mathrm{CO}_{3} \mathrm{Ap}$ samples made of vaterite and DCPA as powder phase with 40:60 powder ratio were mixed with $0.2 \mathrm{~mol} / \mathrm{L} \mathrm{Na}_{2} \mathrm{HPO} 4$, $1 \%$ polyethylene glycol (PEG) and $0.5 \%, 1 \%, 1.5 \%$, and $2 \% \mathrm{NaCMC}$, respectively, as a liquid phase with a ratio liquid to powder of 0.4 to obtain consistency of injectable cement paste. Each group with different $\mathrm{Na} C M C$ concentration has 5 samples. The setting time of $\mathrm{CO}_{3} \mathrm{Ap}$ cement was evaluated according to the modification method standardized by ISO 1566 for dental zinc phosphate cement using a custom fabricated Vicat needle apparatus. The standard requires cement maintained at $37^{\circ} \mathrm{C}$ and $100 \%$ relative humidity. The statistical analysis using one-way factorial ANOVA with Fisher's LSD method as a post hoc test was performed using KaleidaGraph 4.1 (Synergy ${ }^{\circledR}$ Software, PA, USA). The statistical significance level was set at $p<0.05$.

\section{RESULTS}

Table 1 shows the setting time comparison between the various concentration of $\mathrm{Na}$ CMC. Setting time was became longer with increasing the concentration of $\mathrm{Na} \mathrm{CMC}$. The fastest setting time cement with the addition of $0.5 \% \mathrm{Na}$ CMC was 35:06 minutes (in average) with a standard deviation of 0.027 minutes.

Figure 1 shows a statistically significant value with $(p<0.05)$ between group I and II, group I and III, group I and IV, groups II and III, group II and IV, and groups III and IV. The setting time of cement from the fastest to the slowest was in the order of group I < group II < group III < group IV.

\section{DISCUSSION}

Setting time values are influenced by cement reactivity, a particle size of powder, the presence of an additive, molecular weight and fluid concentration, and liquid to powder ratio. ${ }^{10}$ The material tested in this study was an injectable bone cement made by mixing a powder containing calcium phosphate and vaterite with a liquid containing $\mathrm{Na}_{2} \mathrm{HPO} 4$ (as an accelerator) with the addition of $\mathrm{NaCMC}$ to make the consistency of the injectable paste cement. The addition of $\mathrm{Na}$ CMC with various concentration aims to get the consistency of injectable paste and good washout resistance and has the fastest setting time.

In this study, the mean results setting time of injectable bone cement with $0.5 \% \mathrm{Na}$ CMC $35: 06$ minutes, $1 \%$ Na CMC $38: 48$ minutes, $1.5 \%$ Na CMC 40:06 minutes, and 2\% Na CMC 41:30 min. The value of setting time for each group of different samples can be caused by errors of stirring technique, material composition, and the effect of cleanliness of the equipment used.

Bone cement with $0.5 \% \mathrm{Na}$ CMC addition of 35:06 minutes is the cement which has the fastest setting time. This can be due to the lowest amount of additive that is included compared to 
Table 1. The setting time of injectable $\mathrm{CO}_{3} \mathrm{Ap}$ cement mixed with $0.2 \mathrm{~mol} / \mathrm{L} \mathrm{Na} \mathrm{HPO}_{4}$, $1 \%$ polyethylene glycol (PEG) and $\mathrm{Na}$ CMC $0.5 \%, 1 \%, 1.5 \%$, and $2 \%$, respectively

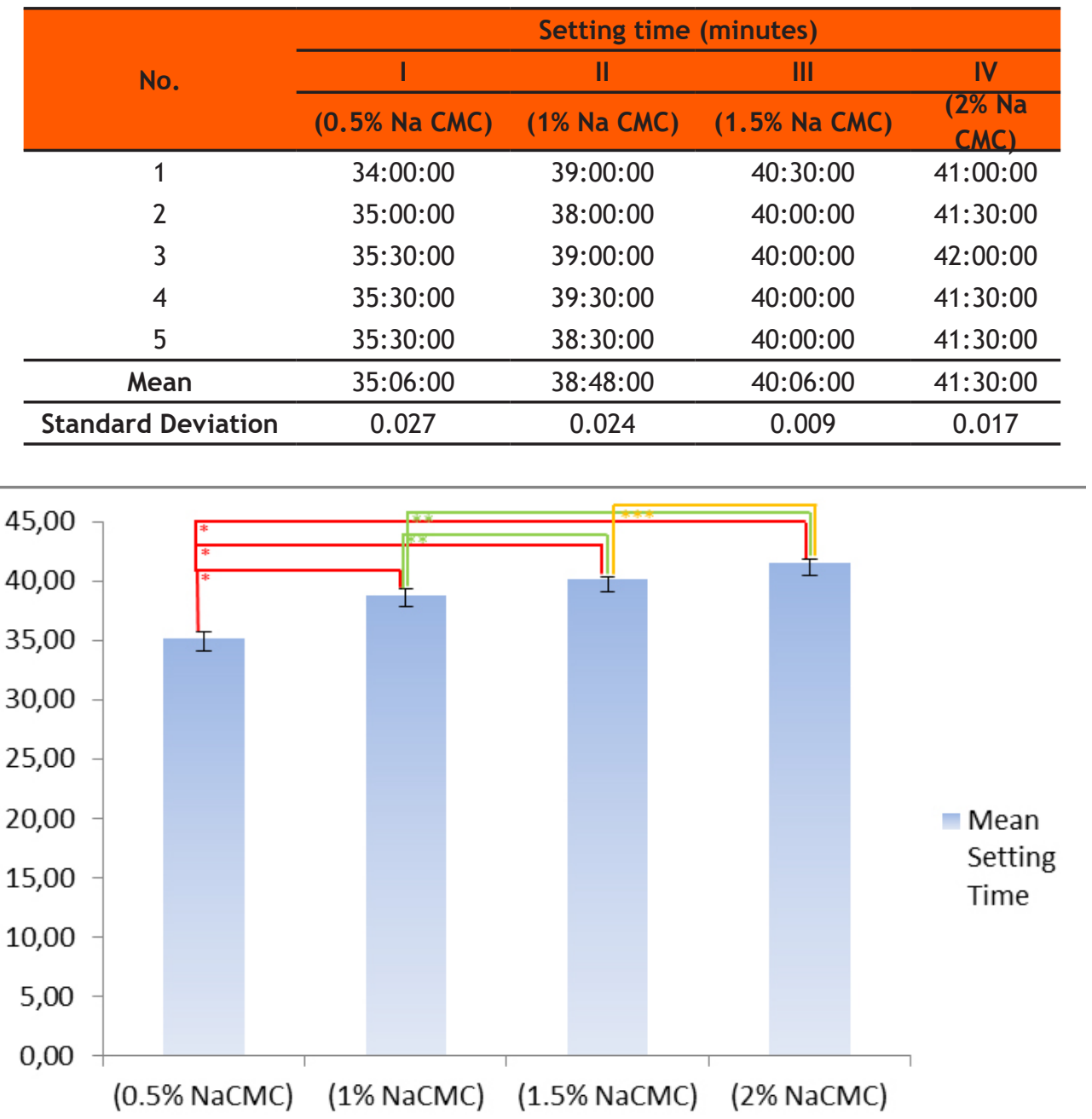

Figure 1. Setting time distribution in order of the fastest to the slowest setting period

other groups. The additives used in this study is $\mathrm{Na}$ CMC. According to a study conducted by Cherng et al. in 1997, carboxymethylcellulose is an additive which inhibits hydroxyapatite formation. CPCs, since the powder is mixed with the liquid that is the process of forming hydroxyapatite until the cement hardened. Cement containing carboxymethylcellulose during the process of hydroxyapatite formation, the cement changes to a washout resistance within 2 minutes, where the change to washout resistance occurs before the cement is hardened, thus raising the hardening time to 60 minutes. Setting time is also influenced by physical properties such as solubility, viscosity, and chain length of polymers such as Na CMC. ${ }^{11}$

Setting time cement containing $0.5 \% \mathrm{Na}$ CMC has a significant difference with $1 \% \mathrm{Na}$
CMC, $1.5 \% \mathrm{Na}$ CMC and $2 \% \mathrm{Na}$ CMC. Whereas the $1 \%$ group was significant compared to $1.5 \%$ and $2 \%$, and $1.5 \%$ significant against $2 \%$. This is consistent with the research of Mishra et al. in 2003 which stated that there is a significant difference in setting time value between $0.5 \%$, $1 \%$, and $2 \%$. This can be caused by the addition of carboxymethylcellulose. Addition of more than $1 \%$ wt will cause microstructure unstable. The frequently used gelling agent concentration is 0.5 $10 \% .{ }^{11}$

Setting time with the similar formulation in previous research by Cahyanto et al. in 2015 which found that the time setting of 11 minutes with vaterite and DCPA as powder phase mixed with a $\mathrm{Na}_{2} \mathrm{HPO}_{4}$ solution with liquid powder ratio of 0.45 . In addition to the additives used in this 
study, the particle size of DCPA powder also has an effect on this research. The larger particle size in this study led to longer time settings. This is due to the less surface area being reacted compared to the smaller particle size.

The solution used in this research is $\mathrm{Na}_{2} \mathrm{HPO}_{4}$. Increasing of $\mathrm{Na}_{2} \mathrm{HPO}_{4}$ may accelerate the setting reaction or increase apatite formation due to increased $\mathrm{PO}_{4}^{3-}$ ions into the cement solution. Addition of $\mathrm{PO}_{4}^{3-}$ ions lead to increased hydroxyapatite supersaturation so that the formation of hydroxyapatite is accelerated, this results shorter the setting time of apatite cement. 1

The source of $\mathrm{CaCO}_{3}$ in this study was obtained by the use of vaterite (one of the $\mathrm{CaCO}_{3}$ polymorphs) as a powder. Vaterite has a higher solubility rate compared to other $\mathrm{CaCO}_{3}$ polymorphs. This is because the size of the vaterite particle is smaller. Particle size is an important factor in the formation of apatite carbonate cement. Vaterite causes setting reactions and the formation of apatite more quickly so as to speed up setting time. . $^{3,4}$,

In $\mathrm{Na}_{2} \mathrm{HPO}_{4}$ solution added another polymer is PEG. The addition of polymers to cement tends to increase the setting time, due to the higher viscosity that blocks the diffusion of ions in the matrix. ${ }^{12}$ Addition of PEG can also increase washout resistance. ${ }^{13}$ PEG can increase the washout resistance so as to extend the cement setting time.

The most appropriate time of injectable bone cement time for clinical application is containing $0.5 \% \mathrm{Na}$ CMC with setting time 35 minutes. Cement with setting time 35 minutes can be used in clinical applications because the change to washout resistance in 2 minutes when applied to bone defects, the cement is not soluble in blood and body fluids.

Based on the setting time value in this study, it can be said that the addition of four kinds of $\mathrm{Na}$ CMC concentration gave a significant effect on the time setting of bone injectable bone, it can be seen from the difference of value of significant time setting between bone semen with the addition of four kinds of Na CMC. Based on the results of the research, the researchers suggest that it should be tried using other additives that can give good injectability cement paste as well as significantly accelerate the material setting time to be used for clinical applications.

\section{CONCLUSION}

There was a difference of various $\mathrm{NaCMC}$ concentration to the mean setting time of injectable bone cement. Increasing the concentration of $\mathrm{NaCMC}$ could prolong the setting time of CO3Ap cement, from the fastest to the slowest setting time was in the order of $0.5 \%<$ $1.0 \%<1.5 \%<2 \% \mathrm{Na}$ CMC.

\section{REFERENCES}

1. Liu C, $\mathrm{HeH}$, eds. Developments and Applications of Calcium Phosphate Bone Cements. Springers Series in Biomaterials Science and Engineering 9. Singapore: Springer Nature Singapore Pte. Ltd.; 2018.

2. Legeros RZ, Trautz OR, Legeros JP, Klein E, Shirra WP. Apatite crystallites: effects of carbonate on morphology. Science. 1967; 155(3768): 1409-11. DOI: 10.1126/ science.155.3768.1409

3. Cahyanto A, Maruta M, Tsuru K, Matsuya S, Ishikawa K. Fabrication of bone cement that fully transforms to carbonate apatite. Dent Mater J. 2015; 34(3): 394-401. DOI: 10.4012/ dmj.2014-328

4. Cahyanto A, Toita R, Tsuru K, Ishikawa K. Effect of Particle Size on Carbonate Apatite Cement Properties Consisting of Calcite ( or Vaterite ) and Dicalcium Phosphate Anhydrous. Key Eng Mater. 2015; 631: 128-33. DOI: 10.4028/www. scientific.net/KEM.631.128

5. Cahyanto A, Maruta M, Tsuru K, Matsuya S, Kunio I. Basic Properties of Carbonate Apatite Cement Consisting of Vaterite and Dicalcium Phosphate Anhydrous. Key Eng Mater. 2013; 530: 192-6. DOI: 10.4028/www.scientific.net/ KEM.529-530.192

6. Jansen J, Ooms E, Verdonschot N, Wolke J. Injectable calcium phosphate cement for bone repair and implant fixation. Orthop Clin North Am. 2005; 36(1): 89-95. DOI: 10.1016/j. ocl.2004.06.014

7. Komath M, Varma HK. Development of a fully injectable calcium phosphate cement for orthopedic and dental applications. Bull 
Mater Sci. 2003; 26(4): 415-22. DOI: $10.1007 /$ BF02711186

8. Ishikawa K, Takagi S, Chow LC, Suzuki K. Reaction of calcium phosphate cements with different amounts of tetracalcium phosphate and dicalcium phosphate anhydrous. J Biomed Mater Res. 1999; 46(4): 504-10.

9. Cherng A, Takagi S, Chow LC. Effects of hydroxypropyl methylcellulose and other gelling agents on the handling properties of calcium phosphate cement. J Biomed Mater Res. 1997; 35(3): 273-7.

10. Anusavice KJ. Phillip's science of dental material. 12st ed. St. Louis: Saunders-Elsevier; 2003. p. 370-4.
11. Mishra PC, Singh VK, Narang KK, Singh NK. Effect of carboxymethyl-cellulose on the properties of cement. Mater Sci Eng. 2003; 357(1-2): 13-9. DOI: 10.1016/S0921. $\underline{5093(02) 00832-8}$

12. Perez RA, Kim HW, Ginebra MP. Polymeric additives to enhance the functional properties of calcium phosphate cements. J Tissue Eng. 2012; 3(1): 204173141243955. DOI: 10.1177/2041731412439555

13. Han B, Ma PW, Zhang LL, Yin YJ, Yao K De, Zhang FJ, et al. B-TCP/MCPM-based premixed calcium phosphate cements. Acta Biomater. 2009; 5(8): 3165-77. DOI: 10.1016/j. actbio.2009.04.024 